\title{
ARTICLE
}

\section{Diet composition for three sciaenids caught off northeastern Brazil}

\author{
Composición de la dieta de tres sciaenidos capturados \\ en el nordeste de Brasil \\ Marcella N. Santos ${ }^{1}$, Gecely R. A. Rocha ${ }^{2, *}$ \\ and Kátia M. F. Freire ${ }^{3}$
}

\begin{abstract}
${ }^{1}$ Universidade Estadual de Santa Cruz, Laboratory of Biological Oceanography, Ilhéus, Bahia, Brazil. marcella_nunes@yahoo.com.br ${ }^{2}$ Universidade Estadual de Santa Cruz, Graduate Program in Tropical Aquatic Systems, Rodovia Jorge Amado, km 16, Ilhéus, Bahia, Brazil. 45662-900. *Corresponding author: gecely@uesc.br

${ }^{3}$ Universidade Federal de Sergipe, Department of Fisheries Engineering and Aquaculture, Laboratory of Fisheries Ecology, Cidade Universitária Prof. José Aloísio de Campos, Rua Mal. Rondon S/N, Jardim Rosa Elze, São Cristóvão, Sergipe, Brazil, 49100-000. kmffreire2015@gmail.com
\end{abstract}

Resumen.- Larimus breviceps, Isopisthus parvipinnis y Paralonchurus brasiliensis son las 3 especies de Sciaenidae más abundantes en la Reserva Extractiva Marina de Corumbau, en Bahia, nordeste de Brasil. Se analizaron los cambios ontogenéticos y estacionales en las dietas de estas especies. Estos cambios pueden reflejar las adaptaciones y mecanismos de coexistencia utilizados por estas especies. El muestreo se llevó a cabo entre diciembre 2007 y septiembre 2008 con arrastreros. Los peces y las gambas fueron los principales recursos consumidos por estas 3 especies. Para L. breviceps y P. brasiliensis, Sergestidae fue el alimento dominante (junto con poliquetos para el segundo), mientras que los peces fueron el elemento más importante para I. parvipinnis. Se observaron valores bajos de amplitud de nicho para todas las especies. El Índice de Similitud de Morisita indicó baja superposición entre las dietas de las 3 especies en la mayoría de las estaciones del año, a excepción de L. breviceps y l. parvipinnis, que mostraron valores superiores al $80 \%$ en todas las estaciones, excepto en verano. Aunque estas especies mostraron diferencias en la posición y orientación de su boca, esencialmente utilizan los mismos recursos. El hábito de alimentación carnívoro, principalmente carcinófago, prevaleció entre los Sciaenidae estudiados.

Palabras clave: Hábitos de alimentación, coexistencia, superposición de nicho, amplitud de nicho, nordeste de Brasil

\begin{abstract}
Larimus breviceps, Isopisthus parvipinnis, and Paralonchurus brasiliensis are the 3 most abundant species of Sciaenidae in the Marine Extractive Reserve of Corumbau in Bahia (northeastern Brazil). Ontogenetic and seasonal changes in the diet of these species were analyzed. These changes may reflect adaptations and coexistence mechanisms used by those species. Sampling took place between December 2007 and September 2008 with otter trawlers. Fishes and shrimps were the main resources consumed by these 3 species. For L. breviceps and P. brasiliensis, Sergestidae was the dominant food item (together with polychaetes for the latter) and fishes were the most important item for I. parvipinnis. Low values of niche breadth were observed for all species. The Morisita Similarity Index indicated a general pattern of low overlap between the diets of the three species analyzed in most of the seasons, with the exception of L. breviceps and I. parvipinnis, which showed values higher than $80 \%$ in all seasons, with the exception of summer. Although these species showed differences in the position and orientation of their mouth, they essentially use the same resources. The carnivorous feeding habit prevailed among the studied Sciaenidae, with predominance of the carcinophagous habit.
\end{abstract}

Key words: Feeding habits, coexistence, niche overlap, niche breadth, northeastern Brazil

\section{INTRODUCTION}

Species of the family Sciaenidae, commonly known as croakers, weakfishes, and drums, are widely distributed, and may be found in the Atlantic, Indian, and Pacific Oceans (Froese \& Pauly 2016). Most of these species are often found in shallow waters of coastal regions, close to large rivers' mouths, over sandy or muddy bottom (Menezes \& Figueiredo 1980), habitats that correspond to traditional Atlantic fishing grounds. This is one of the most abundant groups of demersal fishes found along the
Brazilian coast (Lowe-McConnell 1999), and it is one of the most important components of the demersal fish community in southern and southeastern Brazil (Bail \& Branco 2003). In the northeast region, Sciaenidae also stands out due to the high number of species caught, according to a study carried out by Romero et al. (2008) in Ilhéus (state of Bahia). Although some species are commercially important, such as the whitemouth croaker (Micropogonias furnieri), most species of Sciaenidae 


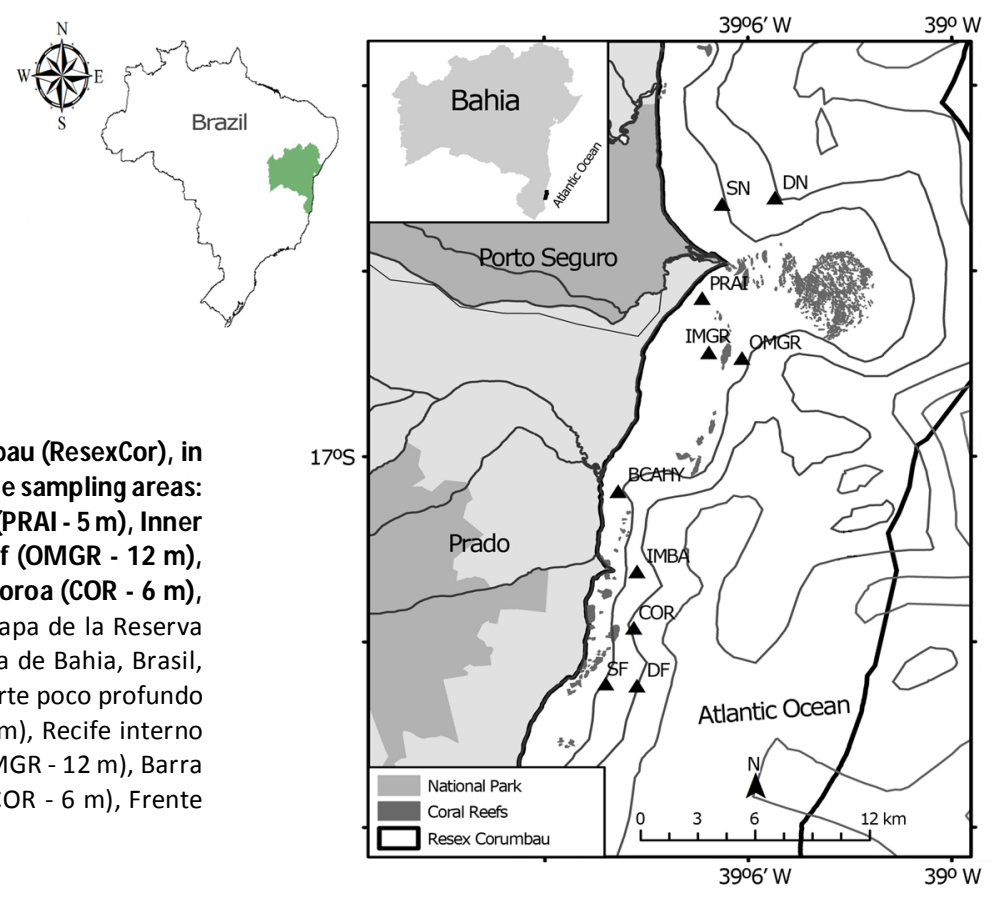

Figure 1. Map of the Marine Extractive Reserve of Corumbau (ResexCor), in the state of Bahia, Brazil, with black triangles indicating the sampling areas: Shallow north (SN - $5 \mathrm{~m}$ ), Deep north (DN - $10 \mathrm{~m}$ ), Prainha (PRAI - $5 \mathrm{~m}$ ), Inner Mato Grosso Reef (IM GR - $7 \mathrm{~m}$ ), Outer Mato Grosso Reef (OM GR - $12 \mathrm{~m}$ ), Barra do Cahy (BCAHY- $6 \mathrm{~m}$ ), Imbassuaba (IM BA - $6 \mathrm{~m}$ ), Coroa (COR - $6 \mathrm{~m}$ ), Shallow front (SF - $5 \mathrm{~m}$ ), and Deep front (DF - $10 \mathrm{~m}$ ) / Mapa de la Reserva Extractiva Marina de Corumbau (ResexCor), en la Província de Bahia, Brasil, con triángulos negros indicando las zonas de muestreo: Norte poco profundo (SN - $5 \mathrm{~m}$ ), Norte profundo (DN - $10 \mathrm{~m}$ ), Prainha (PRAI - $5 \mathrm{~m}$ ), Recife interno Mato Grosso (IMGR - $7 \mathrm{~m}$ ), Recife externo Mato Grosso (OMGR - $12 \mathrm{~m}$ ), Barra do Cahy (BCAHY- $6 \mathrm{~m}$ ), Imbassuaba (IMBA - $6 \mathrm{~m}$ ), Coroa (COR - $6 \mathrm{~m}$ ), Frente poco profundo (SF - $5 \mathrm{~m}$ ), y Frente profundo (DF - $10 \mathrm{~m}$ )

are a major part of bycatch in shrimp trawling operations (Alverson et al. 1994) and small specimens are discarded.

The study of feeding habits is essential to understand the functional role of fishes in an ecosystem, even for species with no commercial interest (Muto et al. 2001). In addition to its importance in number and/or biomass for communities (Meyer \& Smaller 1991), non-commercial species can be predators or competitors of commercially important species, and may interfere with their mortality rate (Muto et al. 2001). Thus, studies on the trophic structure address different aspects of the energy flow and relationships between predator and prey, and consumer and producer. These factors can explain coexistence mechanisms of some species and their contribution as members of the trophic web, in addition to provide a better interpretation of the community's structure (López-Peralta \& Arcila 2002). Additionally, the diet composition is used to build trophic models (Rocha et al. 2007, Freire et al. 2008) and to enable the identification of factors affecting the distribution and abundance of the species investigated, including biological interactions, such as competition and predation (Deus \& Petrere-Júnior 2003, Fonteles-Filho 2011).

One characteristic of competition is that resources are limited (Begon et al. 1996). Thus, to avoid competition, species share resources in different ways, which, according to Ross (1986), explains most of the coexistence mechanisms between closely related species. Moreover, the broad morphological variety observed among species sharing habitats (different tooth types, mouth size and orientation, gill raker size and spacing, intestine size, etc.) reflects adaptations to make use of food items available (Zavala-Camin 1996, Fugi et al. 2001). If there is no sufficient morphological differentiation between two or more species, consumed resources may be similar, resulting in overlapping of niches and inter-specific competition may prevail (Begon et al. 1996).

In this context, the objective of this study was to analyze the diet of the three most abundant species of Sciaenidae (Larimus breviceps, Isopisthus parvipinnis and Paralonchurus brasiliensis) occurring in the Marine Extractive Reserve of Corumbau, in the state of Bahia, and to test the hypothesis that diet overlapping is low among them considering their cooccurrence in high abundance and the difference in their mouth positioning. Even though the diet of these species have been analyzed in other regions (see e.g., Soares 1989, Bessa et al. 2014, Muto et al. 2014), they were never studied in southern Bahia.

\section{Materials ANd Methods}

\section{STUdy AREA}

The Marine Extractive Reserve of Corumbau (ResexCor) was established in September 21, 2000 with an area of about 895 $\mathrm{km}^{2}$ (BRASIL 2000) $^{1}$ (Fig. 1). The reserve is located in the

${ }^{1}$ BRASIL. 2000. Decreto N. 9036, September 21st 2000. Cria a Reserva Extrativista Marinha do Corumbau nos Municípios de Porto Seguro e Prado, Estado da Bahia, e dá outras providências. Diário Oficial [da] República Federativa do Brasil, Brasília, DF, N. 184, p.93, September 22nd 2000, Seção 1[21]. <http://www.planalto.gov.br/ccivil_03/dnn/2000/Dnn9036.htm> 
extreme south of the state of Bahia, between the cities of Porto Seguro and Prado, comprising a fishing area between Ponta do Espelho, at Coruípe Beach (16² $43^{\prime} 20^{\prime \prime S}$ - 3907'11"W), and Barra do Rio das Ostras (17 ${ }^{\circ} 13^{\prime} 29^{\prime \prime S}$ - 39 $\left.{ }^{\circ} 12^{\prime} 51^{\prime \prime W}\right)$. Artisanal fishing is allowed in this category of reserve. Its climate is tropical wet and its waters are dominated by the Brazil Current, responsible for high temperature and salinity throughout the year (Dutra et al. 2002)2.

\section{Data COllection}

Four samplings were carried out from 2007 to 2008: spring (December 2007), summer (March 2008), fall (June 2008), and winter (September 2008). Specimens were collected by shrimp otter trawlers using a net with $30 \mathrm{~mm}$ mesh size in the net body and $26 \mathrm{~mm}$ in the $2 \mathrm{~m}$ long cod-end. Trawling was performed during the morning for an average of $30 \mathrm{~min}$ at a speed of 1.2 nautical miles $\mathrm{h}^{-1}$. The fishing grounds were located between the villages of Corumbau, to the north of ResexCor, and Cumuruxatiba, to the south. The individual sites were (Fig. 1): Shallow north (SN - $5 \mathrm{~m}$ ), Deep north (DN - $10 \mathrm{~m})$, Prainha (PRAI - 5 m), Inner Mato Grosso Reef (IMGR - 7 m), Outer Mato Grosso Reef(OMGR - 12 m), Barra do Cahy (BCAHY$6 \mathrm{~m})$, Imbassuaba (IMBA - $6 \mathrm{~m}$ ), Coroa (COR - $6 \mathrm{~m}$ ), Shallow front (SF - $5 \mathrm{~m}$ ), and Deep front (DF - $10 \mathrm{~m})$.

The species of Sciaenidae caught were identified according to Menezes \& Figueiredo (1980). The diet composition of Larimus breviceps Cuvier, 1830, Isopisthus parvipinnis (Cuvier, 1830) and Paralonchurus brasiliensis (Steindachner, 1875), the 3 most abundant species of Sciaenidae in the area, was studied. Fish specimens were weighed to the nearest gram and had their total length measured to the nearest $\mathrm{mm}$. The mouth orientation of these species was observed (Fig. 2). Stomachs were removed, fixed in $10 \%$ formalin solution and then transferred to $70 \%$ ethanol for analysis of their food contents under stereoscopic microscope. The total number of specimens analyzed was based on sub-samples, selected for stomach content analysis, after excluding individuals whose stomachs were damaged. Gonads were later taken out for macroscopic identification of sex, according to Vazzoler (1996). Stomach contents were identified to the lowest possible taxonomic level (Ruppert \& Barnes 1996). Dendrobranchiata shrimps were identified by Dr. Alexandre Almeida (Laboratory of Animal Histology, Universidade Estadual de Santa Cruz, Bahia). The category 'Others' represents unidentified animal organic matter.
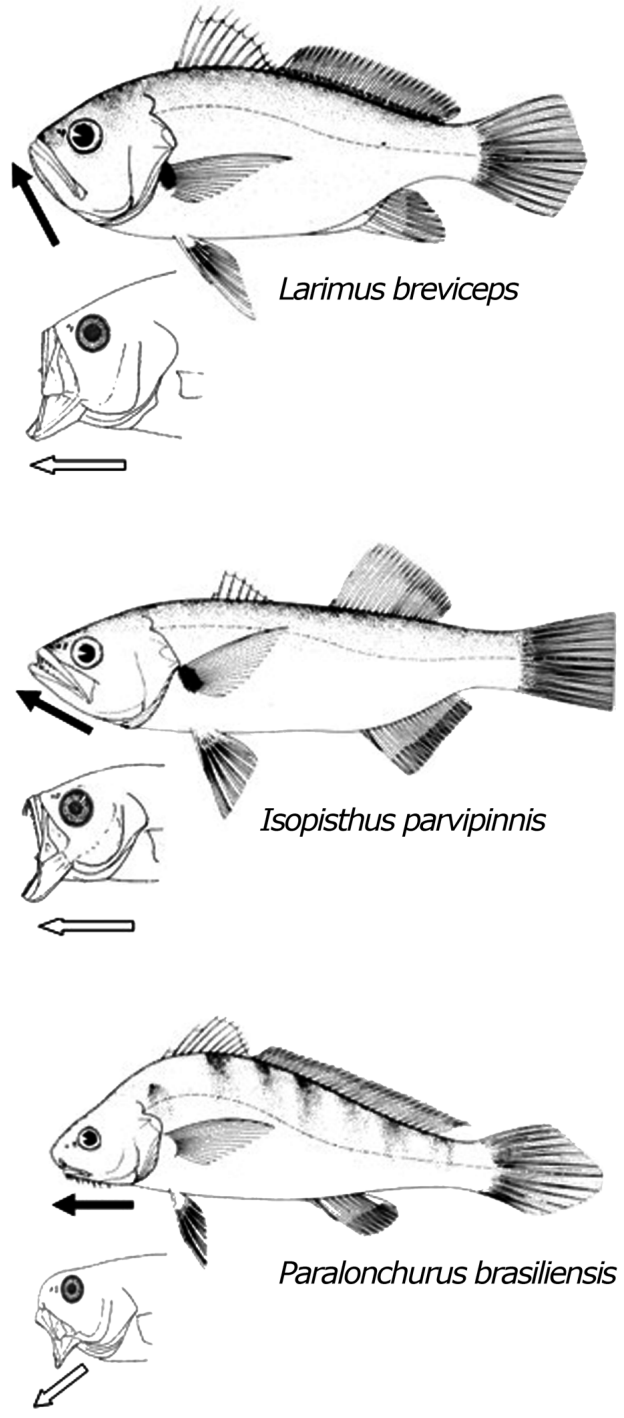

Figure 2. Sciaenidae species studied in the M arine Extractive Reserve of Corumbau. Black arrows indicate the mouth orientation when closed and white arrows, when opened. Source: Jucá-Chagas (1997) and Froese \& Pauly (2016) (modified) / Especies de Sciaenidae estudiadas en la Reserva Extractiva Marina de Corumbau. Setas negras indican la orientación de la boca cuando cerrada y setas blancas, cuando abierta. Fuente: Jucá-Chagas (1997) y Froese \& Pauly (2013) (modificado)

${ }^{2}$ Dutra GF, AZ Cordeiro, RV Carvalho \& S Ortega. 2002. Reserva Extrativista Marinha do Corumbau. Plano de Manejo, Fase I, 15 pp. 


\section{Data ANALysis}

The diet was characterized based on the Frequency of Occurrence (FO, \%), which indicates the proportion of the number of stomachs where a certain type of food item was found in relation to the total number of stomachs examined, and on the volumetric proportion $(\mathrm{V}, \%)$, which measures the relationship between the volume of each type of food item and the total volume of all items found in the stomach (Hyslop 1980, Zavala-Camin 1996). FO and V were used to calculate the Food Index (IAi, \%):

$$
\% I A_{i}=\frac{\% F O_{i} \times \% V_{i}}{\sum_{i}^{n}\left(\% F O_{i} \times \% V_{i}\right)} \times 100
$$

where: $\mathrm{IA}_{\mathrm{i}}=$ food index; $\mathrm{i}=1,2, \ldots \mathrm{n} ; \mathrm{n}=$ total number of types of food items; $\mathrm{FO}_{\mathrm{i}}=$ frequency of occurrence of food item $\mathrm{i}$ in $\% ; \mathrm{V}_{\mathrm{i}}=$ volume of food item $\mathrm{i}$ in relation to the volume of all items, in \% (Kawakami \& Vazzoler 1980). FO and IA were used to investigate ontogenetic and seasonal changes in the diet of the three species.

The degree of stomach fullness was visually estimated considering 4 categories: empty $(0 \%)$, moderate $(0 \%<\mathrm{X} \leq$ $25 \%)$, almost full $(25 \%<\mathrm{X} \leq 75 \%)$ and full $(>75 \%)$ (adapted from Muto et al. 2001).

The Levin's measure was used to analyze the niche of each species:

$$
B=\frac{1}{\sum p_{j}^{2}}
$$

where: $\mathrm{B}=$ Levin's measure of niche breadth; $\mathrm{p}_{\mathrm{j}}=$ proportion of individuals using resource $j$ or fraction of item $j$ in the diet (Krebs 1989). It measures the uniformity of distribution of individuals among the types of resource. Thus, $B$ is maximum when an equal number of individuals is recorded for each type of food resource, and minimal when all prey items correspond to only one type of resource (minimum niche breadth, maximum specialization). Thus, the value of $\mathrm{B}$ will be higher when more items are consumed in equal proportions.

The Morisita Index was used to verify the diet overlap between each pair of species analyzed:

$$
C H_{j k}=\frac{2 \sum_{i}^{n} p_{i j} \cdot p_{i k}}{\sum_{i}^{n} p_{i j}^{2}+\sum_{i}^{n} p_{i k}^{2}}
$$

$\mathrm{CH}_{\mathrm{jk}}=$ Simplified Morisita Index of diet overlap between species $j$ and $k ; \mathrm{p}_{\mathrm{ij}}=$ proportion of food category $i$ in relation to the total number of items consumed by species $j ; \mathrm{p}_{\mathrm{ik}}=$ proportion of food category $i$ in relation to the total number of items consumed by species $k ; \mathrm{n}=$ total number of food categories $(i=1,2,3, \ldots, \mathrm{n})($ Krebs 1989). Values higher than 0.5 indicate high diet overlap.

The Unweighted Pair Group Method (UPGMA) for cluster analysis and the Modified Morisita Similarity Coefficient were applied to compare the diet composition, using the software MVSP 3.1 (Multivariate Statistical Package).

\section{Results}

\section{Feeding ECOLOGY}

\section{Larimus breviceps}

A total of 498 stomachs of L. breviceps were analyzed, and 12 food categories were identified. Dendrobranchiata were identified using eyes and fragments of the carapace. These shrimps showed high $\mathrm{IA}_{i}$ in all seasons, with highest totals in the summer (Table 1). Two families of Dendrobranchiata were identified: Sergestidae and Penaeidae. Sergestidae was more frequently consumed throughout the year, except in the summer, with highest values of IA in the fall (26.2\%) and winter (15.5\%). Fishes were also present in diet of this species, with higher IA in the spring and fall. The high degree of digestion did not allow the identification of some specimens, which were grouped in the category 'unidentified fishes'. Among those that could be identified, individuals of the families Engraulidae and Sciaenidae were observed. Both families presented higher $\mathrm{IA}_{\mathrm{i}}$ in the fall.

Empty stomachs accounted for only $5 \%$ of the total analyzed for this species in all seasons, with lower occurrence in the fall (Table 1 ). In the spring, about $52 \%$ of the stomachs analyzed were up to $25 \%$ filled with food; in the summer this percentage was higher.

Throughout the year, L. breviceps showed low values of niche breadth, especially in summer, when the diet of the species was composed mainly by Dendrobranchiata shrimps. The largest value was recorded in the fall $(B=3.29)$, when a lower dominance of shrimps and a small increase in fish consumption were observed (Table 1).

In two size classes for $L$. breviceps, Dendrobranchiata was the most important category, with IA of about $94 \%$ for individuals up to $10 \mathrm{~cm}$ long and $77 \%$ for individuals $10-20 \mathrm{~cm}$ long (Table 2). Only three individuals $20-30 \mathrm{~cm}$ long were found in the samples. Thus, this class was removed from the analysis. 
Table 1. Seasonal variation of the food categories for Larimus breviceps in the Marine Extractive Reserve of Corumbau. Frequency of occurrence $(\% \mathrm{FO})$, volume (\%V), Food Index (\% $1 \mathrm{Ai})$, degree of stomach fullness (\%), niche breadth (B), number of stomachs analyzed (N), and total length (TL, cm). * Non-identified animal organic matter due to the high degree of digestion and polychaete tubes / Variación estacional de las categorías tróficas de Larimus breviceps en la Reserva Extractiva Marina de Corumbau. Frecuencia de ocurrencia (\%FO), volumen (\%V), Índice Alimentario (\%IAi), amplitud de nicho (B), repleción estomacal (\%), número de estómagos analizados (N), y longitud total (TL, cm). *Materia orgánica animal no identificada por la elevada digestión y tubos de poliquetos

\begin{tabular}{|c|c|c|c|c|c|c|c|c|c|c|c|c|}
\hline & \multicolumn{3}{|c|}{$\begin{array}{c}\text { DEC/07 } \\
\text { Spring }\end{array}$} & \multicolumn{3}{|c|}{$\begin{array}{l}\text { MAR/08 } \\
\text { Summer }\end{array}$} & \multicolumn{3}{|c|}{$\begin{array}{c}\mathrm{JUN} / 08 \\
\text { Fall }\end{array}$} & \multicolumn{3}{|c|}{$\begin{array}{l}\text { SEP/08 } \\
\text { Winter }\end{array}$} \\
\hline & $\% \mathrm{FO}$ & $\% \mathrm{~V}$ & $\% \mathrm{IA}_{\mathrm{i}}$ & $\% \mathrm{FO}$ & $\% \mathrm{~V}$ & $\% \mathrm{IA}_{\mathrm{i}}$ & $\% \mathrm{FO}$ & $\% \mathrm{~V}$ & $\% \mathrm{IA}_{\mathrm{i}}$ & $\% \mathrm{FO}$ & $\% \mathrm{~V}$ & $\% \mathrm{IA}_{\mathrm{i}}$ \\
\hline \multicolumn{13}{|l|}{ Food Category } \\
\hline Unidentified Dendrobranchiata & 71.8 & 53.5 & 83.9 & 62.9 & 75.0 & 89.6 & 78.7 & 41.2 & 68.5 & 69.2 & 56.0 & 83.0 \\
\hline Sergestidae & 18.4 & 34.5 & 13.9 & 2.4 & 2.4 & 0.1 & 36.1 & 34.4 & 26.2 & 24.6 & 29.3 & 15.5 \\
\hline Penaeidae & 3.1 & 2.1 & 0.1 & 2.4 & 3.9 & 0.2 & 5.7 & 3.3 & 0.4 & 4.6 & 2.6 & 0.3 \\
\hline Isopoda & 3.7 & 0.3 & 0.0 & 0.0 & 0.0 & 0.0 & 2.5 & 0.2 & 0.0 & 1.5 & 0.6 & 0.0 \\
\hline Amphipoda & 1.2 & 0.0 & 0.0 & 0.0 & 0.0 & 0.0 & 0.0 & 0.0 & 0.0 & 0.0 & 0.0 & 0.0 \\
\hline Unidentified fish & 16.6 & 3.9 & 1.4 & 8.1 & 4.0 & 0.6 & 18.9 & 9.8 & 3.9 & 1.5 & 0.5 & 0.0 \\
\hline Engraulidae & 0.0 & 0.0 & 0.0 & 0.0 & 0.0 & 0.0 & 3.3 & 6.3 & 0.4 & 0.0 & 0.0 & 0.0 \\
\hline Sciaenidae & 1.2 & 1.9 & 0.1 & 0.0 & 0.0 & 0.0 & 3.3 & 2.8 & 0.2 & 1.5 & 7.7 & 0.3 \\
\hline Cephalopoda (squid) & 0.6 & 1.6 & 0.0 & 0.0 & 0.0 & 0.0 & 0.0 & 0.0 & 0.0 & 0.0 & 0.0 & 0.0 \\
\hline Bivalvia & 0.6 & 0.0 & 0.0 & 0.0 & 0.0 & 0.0 & 0.0 & 0.0 & 0.0 & 0.0 & 0.0 & 0.0 \\
\hline Plant material & 0.6 & 0.0 & 0.0 & 0.0 & 0.0 & 0.0 & 0.0 & 0.0 & 0.0 & 0.0 & 0.0 & 0.0 \\
\hline Other* & 8.0 & 3.6 & 1.0 & 33.9 & 14.7 & 9.0 & 9.0 & 1.9 & 0.0 & 16.9 & 3.3 & 1.0 \\
\hline \multicolumn{13}{|l|}{ Stomach fullness (\%) } \\
\hline Empty (0) & \multicolumn{3}{|c|}{3.0} & \multicolumn{3}{|c|}{3.1} & \multicolumn{3}{|c|}{0.8} & \multicolumn{3}{|c|}{19.2} \\
\hline Moderate $(0<X \leq 25)$ & \multicolumn{3}{|c|}{52.4} & \multicolumn{3}{|c|}{77.3} & \multicolumn{3}{|c|}{34.7} & \multicolumn{3}{|c|}{50.0} \\
\hline Almost full $(25<\mathrm{X} \leq 75)$ & \multicolumn{3}{|c|}{33.9} & \multicolumn{3}{|c|}{11.7} & \multicolumn{3}{|c|}{33.9} & \multicolumn{3}{|c|}{21.8} \\
\hline Full $(>75)$ & \multicolumn{3}{|c|}{10.7} & \multicolumn{3}{|c|}{7.8} & \multicolumn{3}{|c|}{30.6} & \multicolumn{3}{|c|}{9.0} \\
\hline $\mathrm{B}$ & \multicolumn{3}{|c|}{2.44} & \multicolumn{3}{|c|}{1.70} & \multicolumn{3}{|c|}{3.29} & \multicolumn{3}{|c|}{2.46} \\
\hline $\mathrm{N}$ & \multicolumn{3}{|c|}{168} & \multicolumn{3}{|c|}{128} & \multicolumn{3}{|c|}{124} & \multicolumn{3}{|c|}{78} \\
\hline TL (min-max) & \multicolumn{3}{|c|}{$6.1-22.0$} & & $8.7-15.3$ & & & $3.8-18.8$ & & & $6.5-48.9$ & \\
\hline
\end{tabular}

Table 2. Ontogenetic variation of food items found in the stomach content of species of Sciaenidae in the Marine Extractive Reserve of Corumbau, based on the Food Index (\%IAi). Total length class (cm): 1-10; 10-20; 20-30; number of stomachs analyzed (N).* Others: non-identified animal organic matter due to the high degree of digestion; in I. parvipinnis and P. brasiliensis includes plant material. DAOM = Digested animal organic matter / Variación ontogenética de ítems alimenticios encontrados en los contenidos estomacales de especies de Sciaenidae en la Reserva Extractiva Marina de Corumbau, basada en el Índice Alimentario (\%IAi). Clases de talla total $(\mathrm{cm})$ : 1-10; 10-20; 20-30; número de estómagos analizados (N). *Otros: materia orgánica animal no identificada por la elevada digestión; en I. parvipinnis y P. brasiliensis incluye material vegetal. DAOM = materia orgánica animal digerida

\begin{tabular}{|c|c|c|c|c|c|c|c|c|}
\hline & \multicolumn{2}{|c|}{$\begin{array}{l}\text { Larimus } \\
\text { breviceps }\end{array}$} & \multicolumn{3}{|c|}{ Isopisthus parvipinnis } & \multicolumn{3}{|c|}{$\begin{array}{c}\text { Paralonchurus } \\
\text { brasiliensis }\end{array}$} \\
\hline & $1-10$ & $10-20$ & $1-10$ & $10-20$ & $20-30$ & $1-10$ & $10-20$ & $20-30$ \\
\hline \multicolumn{9}{|l|}{ Food category } \\
\hline Unidentified Dendrobranchiata & 94.4 & 77.1 & 91.1 & 52.6 & 41.7 & 59.8 & 59.3 & 63.0 \\
\hline Sergestidae & 3.3 & 18.6 & 0.1 & 0.2 & 0.0 & 0.0 & 0.2 & 0.0 \\
\hline Penaeidae & 0.1 & 0.3 & 2.4 & 0.4 & 7.4 & 0.0 & 0.0 & 0.0 \\
\hline Unidentified fish & 0.8 & 2.0 & 4.7 & 28.9 & 1.6 & 0.1 & 0.1 & 0.0 \\
\hline Engraulidae & 0.0 & 0.1 & 0.0 & 0.4 & 0.0 & 0.0 & 0.0 & 0.0 \\
\hline Sciaenidae & 0.0 & 0.1 & 0.1 & 0.3 & 0.0 & 0.0 & 0.0 & 0.0 \\
\hline Clupeidae & 0.0 & 0.0 & 0.0 & 1.0 & 0.0 & 0.0 & 0.0 & 0.0 \\
\hline DAOM Polychaeta & 0.0 & 0.0 & 0.0 & 0.0 & 0.0 & 13.9 & 27.3 & 5.3 \\
\hline Plant material & 0.0 & 0.0 & 0.0 & 0.0 & 0.1 & 0.1 & 0.0 & 0.0 \\
\hline Sediment & 0.0 & 0.0 & 0.0 & 0.0 & 0.0 & 0.1 & 0.1 & 0.0 \\
\hline Others* & 1.3 & 1.7 & 1.5 & 16.1 & 49.3 & 26.0 & 13.1 & 31.7 \\
\hline $\mathrm{N}$ & 182 & 286 & 145 & 140 & 13 & 65 & 154 & 9 \\
\hline
\end{tabular}




\section{Isopisthus parvipinnis}

Nine food categories were identified in 395 analyzed stomachs. The category Dendrobranchiata n.i. was important throughout the year, accounting for $67 \%$ of the IAi in the spring and about $80 \%$ in the fall (Table 3 ). Similar to the diet of L. breviceps, Sergestidae and Penaeidae were found in the stomach contents. Fishes were the second most abundant food category in the diet of I. parvipinnis, showing the highest values of IAi in the fall $(15 \%)$ and winter $(16 \%)$. In addition to the families Engraulidae and Sciaenidae, also ingested by L. breviceps, $I$. parvipinnis ingested clupeids, but with low $\mathrm{IA}_{\mathrm{i}}$ values, mainly in the winter $(2.3 \%)$.

Of the total of stomachs analyzed, only $10 \%$ were full, whereas most stomachs were classified as moderate (fullness degree: $0 \%<X \leq 25 \%$ ), especially in the summer $(93.7 \%$ ) (Table 3). In this season, due to the high degree of digestion of food consumed, only Dendrobranchiata shrimps were identified $\left(\mathrm{IA}_{\mathrm{i}}=41.1 \%\right)$. The lowest niche breadth was recorded in the summer $(B=2.00)$ and the largest in the winter $(B=5.17)$, when fishes and shrimps (Sergestidae and Penaeidae) were consumed in similar proportions.

Dendrobranchiata shrimps dominated the diet of all size classes. Shrimps were largely consumed, mainly by individuals of up to $10 \mathrm{~cm}$ long, with an $\mathrm{IA}_{\mathrm{i}}$ of around $91 \%$. However, these percentages decreased among individuals $10-20 \mathrm{~cm}$ long, which ingested higher number of fishes $\left(\mathrm{IA}_{\mathrm{i}}=28.9 \%\right.$ ) (Table 2).

\section{Paralonchurus brasiliensis}

Nine food categories were identified in 242 analyzed stomachs. The highest IA $_{i}$ values observed were represented by polychaetes in spring and fall and by Dendrobranchiata shrimps in summer and winter (Table 4). Among the shrimps that could be identified, Sergestidae were more important than Penaeidae. Other crustaceans, such as amphipods, were also identified in the diet of $P$. brasiliensis, but only in the winter. For this species, the category 'Others' includes polychaete tubes besides animal organic matter of unidentified origin.

Table 3. Seasonal variation of the food categories for Isopisthus parvipinnis in the Marine Extractive Reserve of Corumbau. Frequency of occurrence $(\% \mathrm{FO})$, volume (\%V), Food Index (\%Ai), degree of stomach fullness (\%), niche breadth (B), number of stomachs analyzed (N), and total length (TL, cm). * Non-identified animal organic matter due to the high degree of digestion / Variación estacional de las categorías tróficas de lsopisthus parvipinnis en la Reserva Extractiva Marina de Corumbau. Frecuencia de ocurrencia (\%FO), volumen (\%V), Índice Alimentario (\% $1 \mathrm{Ai})$, amplitud de nicho (B), repleción estomacal (\%), numero de estómagos analizados (N), y talla total $(\mathrm{TL}, \mathrm{cm})$. *Materia orgánica animal no identificada por la elevada digestión

\begin{tabular}{|c|c|c|c|c|c|c|c|c|c|c|c|c|}
\hline & \multicolumn{3}{|c|}{$\begin{array}{c}\text { DEC/07 } \\
\text { Spring }\end{array}$} & \multicolumn{3}{|c|}{$\begin{array}{l}\text { MAR/08 } \\
\text { Summer }\end{array}$} & \multicolumn{3}{|c|}{$\begin{array}{c}\text { JUN/08 } \\
\text { Fall }\end{array}$} & \multicolumn{3}{|c|}{$\begin{array}{l}\mathrm{SEP} / 08 \\
\text { Winter }\end{array}$} \\
\hline & $\% \mathrm{FO}$ & $\% \mathrm{~V}$ & $\% \mathrm{IA}_{\mathrm{i}}$ & $\% \mathrm{FO}$ & $\% \mathrm{~V}$ & $\% \mathrm{IA}_{\mathrm{i}}$ & $\% \mathrm{FO}$ & $\% \mathrm{~V}$ & $\% \mathrm{IA}_{\mathrm{i}}$ & $\% \mathrm{FO}$ & $\% \mathrm{~V}$ & $\% \mathrm{IA}_{\mathrm{i}}$ \\
\hline \multicolumn{13}{|l|}{ Food category } \\
\hline Unidentified Dendrobranchiata & 52.0 & 43.6 & 67.0 & 40.0 & 51.2 & 41.1 & 62.1 & 47.1 & 80.3 & 46.1 & 22.6 & 51.7 \\
\hline Sergestidae & 0.0 & 0.0 & 0.0 & 0.0 & 0.0 & 0.0 & 1.2 & 0.7 & 0.0 & 7.9 & 4.6 & 1.8 \\
\hline Penaeidae & 0.0 & 0.0 & 0.0 & 0.0 & 0.0 & 0.0 & 7.7 & 9.7 & 2.0 & 7.9 & 15.9 & 6.2 \\
\hline Unidentified fish & 12.0 & 20.1 & 7.0 & 0.0 & 0.0 & 0.0 & 20.1 & 28.1 & 15.5 & 13.2 & 25.6 & 16.8 \\
\hline Engraulidae & 2.0 & 10.0 & 5.0 & 0.0 & 0.0 & 0.0 & 0.6 & 0.8 & 0.0 & 0.0 & 0.0 & 0.0 \\
\hline Sciaenidae & 0.0 & 0.0 & 0.0 & 0.0 & 0.0 & 0.0 & 2.4 & 9.9 & 0.6 & 0.0 & 0.0 & 0.0 \\
\hline Clupeidae & 2.0 & 8.0 & 0.0 & 0.0 & 0.0 & 0.0 & 0.6 & 0.8 & 0.0 & 2.6 & 17.2 & 2.3 \\
\hline Plant material & 0.0 & 0.0 & 0.0 & 0.0 & 0.0 & 0.0 & 0.6 & 0.1 & 0.0 & 0.0 & 0.0 & 0.0 \\
\hline Others & 38.0 & 18.2 & 20.0 & 60.0 & 48.8 & 59.0 & 14.8 & 3.5 & 1.0 & 30.3 & 14.1 & 21.0 \\
\hline \multicolumn{13}{|l|}{ Stomach fullness (\%) } \\
\hline Empty (0) & \multicolumn{3}{|c|}{24} & \multicolumn{3}{|c|}{0} & \multicolumn{3}{|c|}{27.8} & \multicolumn{3}{|c|}{20} \\
\hline Moderate $(0<X \leq 25)$ & \multicolumn{3}{|c|}{62} & \multicolumn{3}{|c|}{93.7} & \multicolumn{3}{|c|}{42.3} & \multicolumn{3}{|c|}{55.8} \\
\hline Almost full $(25<\mathrm{X} \leq 75)$ & \multicolumn{3}{|c|}{12} & \multicolumn{3}{|c|}{6.2} & \multicolumn{3}{|c|}{17.9} & \multicolumn{3}{|c|}{10.5} \\
\hline Full $(>75)$ & \multicolumn{3}{|c|}{2} & \multicolumn{3}{|c|}{0} & \multicolumn{3}{|c|}{12} & \multicolumn{3}{|c|}{13.7} \\
\hline B & \multicolumn{3}{|c|}{3.57} & \multicolumn{3}{|c|}{2.00} & \multicolumn{3}{|c|}{3.11} & \multicolumn{3}{|c|}{5.17} \\
\hline $\mathrm{N}$ & \multicolumn{3}{|c|}{50} & \multicolumn{3}{|c|}{16} & \multicolumn{3}{|c|}{234} & \multicolumn{3}{|c|}{95} \\
\hline TL (min-max) & \multicolumn{3}{|c|}{$7.4-28.4$} & \multicolumn{3}{|c|}{$11.0-22.5$} & \multicolumn{3}{|c|}{$3.9-23.5$} & & $3.6-22.2$ & \\
\hline
\end{tabular}


Table 4. Seasonal variation of the food categories for Paralonchurus brasiliensis in the Marine Extractive Reserve of Corumbau. Frequency of occurrence (\%FO), volume (\%V), Food Index (\%IAi), degree of stomach fullness (\%), niche breadth (B), number of stomachs analyzed (N), and total length (TL, $\mathrm{cm})$. * Non-identified animal organic matter due to the high degree of digestion / Variación estacional de las categorías tróficas de Paralonchurus brasiliensis en la Reserva Extractiva Marina de Corumbau. Frecuencia de ocurrencia (\%FO), volumen (\%V), Índice Alimentario (\%IAi), amplitud de nicho (B), repleción estomacal (\%), numero de estómagos analizados $(\mathrm{N})$, y talla total $(\mathrm{TL}, \mathrm{cm}) .{ }^{*}$ Materia orgánica animal no identificada por la elevada digestión

\begin{tabular}{|c|c|c|c|c|c|c|c|c|c|c|c|c|}
\hline & \multicolumn{3}{|c|}{$\begin{array}{c}\text { DEC/07 } \\
\text { Spring }\end{array}$} & \multicolumn{3}{|c|}{$\begin{array}{l}\text { MAR/08 } \\
\text { Summer }\end{array}$} & \multicolumn{3}{|c|}{$\begin{array}{c}\text { JUN/08 } \\
\text { Fall }\end{array}$} & \multicolumn{3}{|c|}{$\begin{array}{l}\text { SEP/08 } \\
\text { Winter }\end{array}$} \\
\hline & $\% \mathrm{FO}$ & $\% \mathrm{~V}$ & $\% \mathrm{IA}_{\mathrm{i}}$ & $\% \mathrm{FO}$ & $\% \mathrm{~V}$ & $\% \mathrm{IA}_{\mathrm{i}}$ & $\% \mathrm{FO}$ & $\% \mathrm{~V}$ & $\% \mathrm{IA}_{\mathrm{i}}$ & $\% \mathrm{FO}$ & $\% \mathrm{~V}$ & $\% \mathrm{IA}_{\mathrm{i}}$ \\
\hline \multicolumn{13}{|l|}{ Food category } \\
\hline Unidentified Dendrobranchiata & 61.5 & 10.4 & 24.4 & 27.3 & 36.2 & 27.1 & 60.7 & 24.9 & 28.3 & 58.6 & 53.0 & 75.6 \\
\hline Sergestidae & 7.7 & 4.6 & 1.2 & 0.0 & 0.0 & 0.0 & 14.3 & 8.2 & 2.5 & 1.7 & 0.5 & 0.0 \\
\hline Penaeidae & 3.1 & 2.8 & 0.3 & 0.0 & 0.0 & 0.0 & 0.0 & 0.0 & 0.0 & 0.0 & 0.0 & 0.0 \\
\hline Amphipoda & 0.0 & 0.0 & 0.0 & 0.0 & 0.0 & 0.0 & 0.0 & 0.0 & 0.0 & 1.7 & 0.1 & 0.0 \\
\hline Unidentified fish & 1.5 & 4.6 & 0.3 & 2.6 & 1.5 & 0.1 & 0.0 & 0.0 & 0.0 & 0.0 & 0.0 & 0.0 \\
\hline Polychaeta & 24.6 & 31.4 & 29.3 & 13.0 & 19.7 & 7.0 & 57.1 & 64.5 & 69.0 & 31.0 & 23.2 & 17.5 \\
\hline Sediment & 3.1 & 2.8 & 0.3 & 0.0 & 0.0 & 0.0 & 0.0 & 0.0 & 0.0 & 5.2 & 2.2 & 0.3 \\
\hline Plant material & 0.0 & 0.0 & 0.0 & 2.6 & 2.8 & 0.2 & 10.7 & 0.1 & 0.2 & 0.0 & 0.0 & 0.0 \\
\hline Others* & 24.6 & 48.7 & 45.0 & 59.7 & 39.9 & 66.0 & 10.7 & 1.5 & 0.0 & 19.0 & 20.1 & 6.0 \\
\hline \multicolumn{13}{|l|}{ Stomach fullness (\%) } \\
\hline Empty (0) & \multicolumn{3}{|c|}{4.4} & \multicolumn{3}{|c|}{9.3} & \multicolumn{3}{|c|}{12.9} & \multicolumn{3}{|c|}{0} \\
\hline Moderate $(0<\mathrm{X} \leq 25)$ & \multicolumn{3}{|c|}{55.9} & \multicolumn{3}{|c|}{73.3} & \multicolumn{3}{|c|}{45.16} & \multicolumn{3}{|c|}{66.7} \\
\hline Almost full $(25<\mathrm{X} \leq 75)$ & \multicolumn{3}{|c|}{32.4} & \multicolumn{3}{|c|}{14.0} & \multicolumn{3}{|c|}{22.58} & \multicolumn{3}{|c|}{22.8} \\
\hline Full $(>75)$ & \multicolumn{3}{|c|}{7.4} & \multicolumn{3}{|c|}{3.5} & \multicolumn{3}{|c|}{19.35} & \multicolumn{3}{|c|}{10.5} \\
\hline B & \multicolumn{3}{|c|}{2.86} & \multicolumn{3}{|c|}{3.03} & \multicolumn{3}{|c|}{2.06} & \multicolumn{3}{|c|}{2.78} \\
\hline $\mathrm{N}$ & \multicolumn{3}{|c|}{68} & \multicolumn{3}{|c|}{86} & \multicolumn{3}{|c|}{31} & \multicolumn{3}{|c|}{57} \\
\hline TL (min-max) & \multicolumn{3}{|c|}{$5.7-21.7$} & \multicolumn{3}{|c|}{$5.8-22.0$} & \multicolumn{3}{|c|}{$4.7-19.4$} & & $4.6-23.5$ & \\
\hline
\end{tabular}

About $63 \%$ of stomachs examined for this species were up to $25 \%$ filled with food and only 6 were empty. Moderate stomachs were more frequent in the summer, when only $3.5 \%$ of the stomachs were full (Table 4). The widest niche breadth for $P$. brasiliensis was observed in spring and summer, when the dominance of polychaetes and Dendrobranchiata shrimps was lower. On the other hand, the lowest niche breadth was recorded in the fall, when high values of $\mathrm{IA}_{\mathrm{i}}$ were observed for polychaetes and Dendrobranchiata.

Dendrobranchiata was equally important in all size classes identified for $P$. brasiliensis, followed by polychaetes, which were particularly important to individuals $10-20 \mathrm{~cm}$ long (Table 2).

\section{Diet OVERLaP}

The Morisita Similarity Index exhibited a general pattern of low overlap between the diets of the three species analyzed (Fig. 3 ). In spring, summer and fall, the diet overlap between $P$. brasiliensis and L. breviceps was low $\left(\mathrm{CH}_{\mathrm{jk}}<0.50\right)$, reflecting low values of Dendrobranchiata shrimps observed in the diet of $P$. brasiliensis, in contrast to values twice or three times higher for $L$. breviceps. A similar pattern was observed for $P$. brasiliensis and I. parvipinnis, with low diet overlap specially in summer $\left(\mathrm{CH}_{\mathrm{jk}}=0.22\right)$. In the fall, P. brasiliensis showed low similarity with the diet of other species, due to a higher abundance of polychaetes in its diet. 


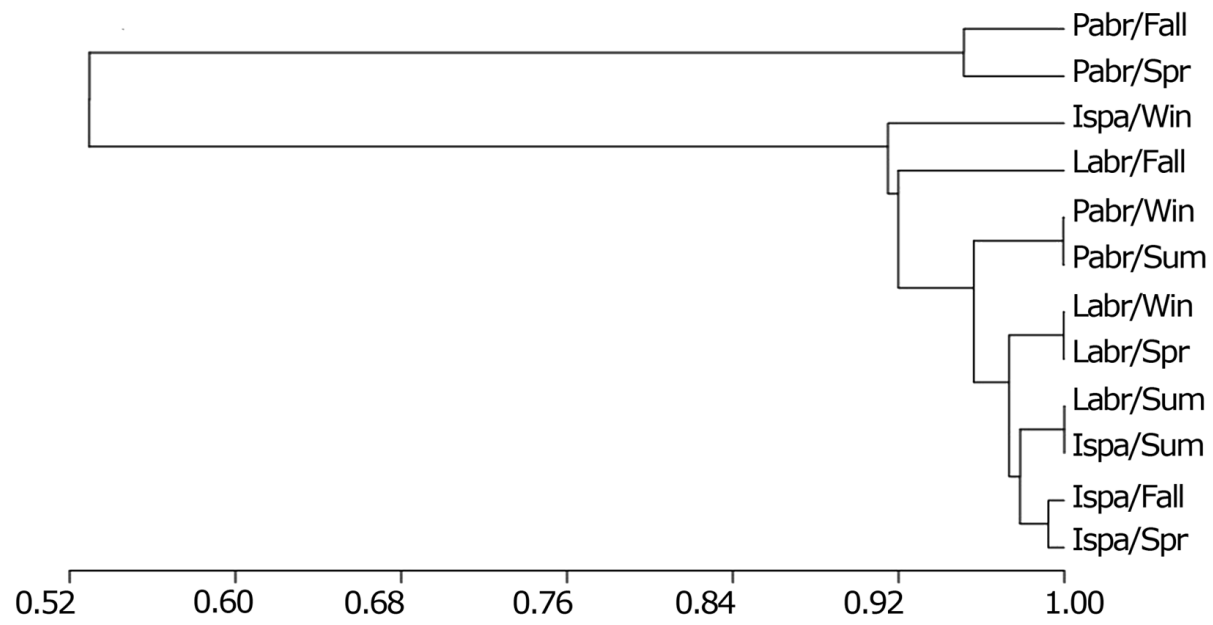

Figure 3. Seasonal feeding similarity between the species of Sciaenidae according to the M odified M orisita Similarity Coefficient (Labr: Larimus breviceps; Ispa: Isopisthus parvipinnis; Pabr: Paralonchurus brasiliensis; Spr: spring; Sum: summer; Fall: fall; Win: winter) / Similitud alimentaria estacional entre especies de Sciaenidae de acuerdo con el Coeficiente de Similitud Modificado de Morisita (Labr: Larimus breviceps; Ispa: Isopisthus parvipinnis; Pabr: Paralonchurus brasiliensis; Spr: primavera; Sum: verano; Fall: otoño; Win: invierno)

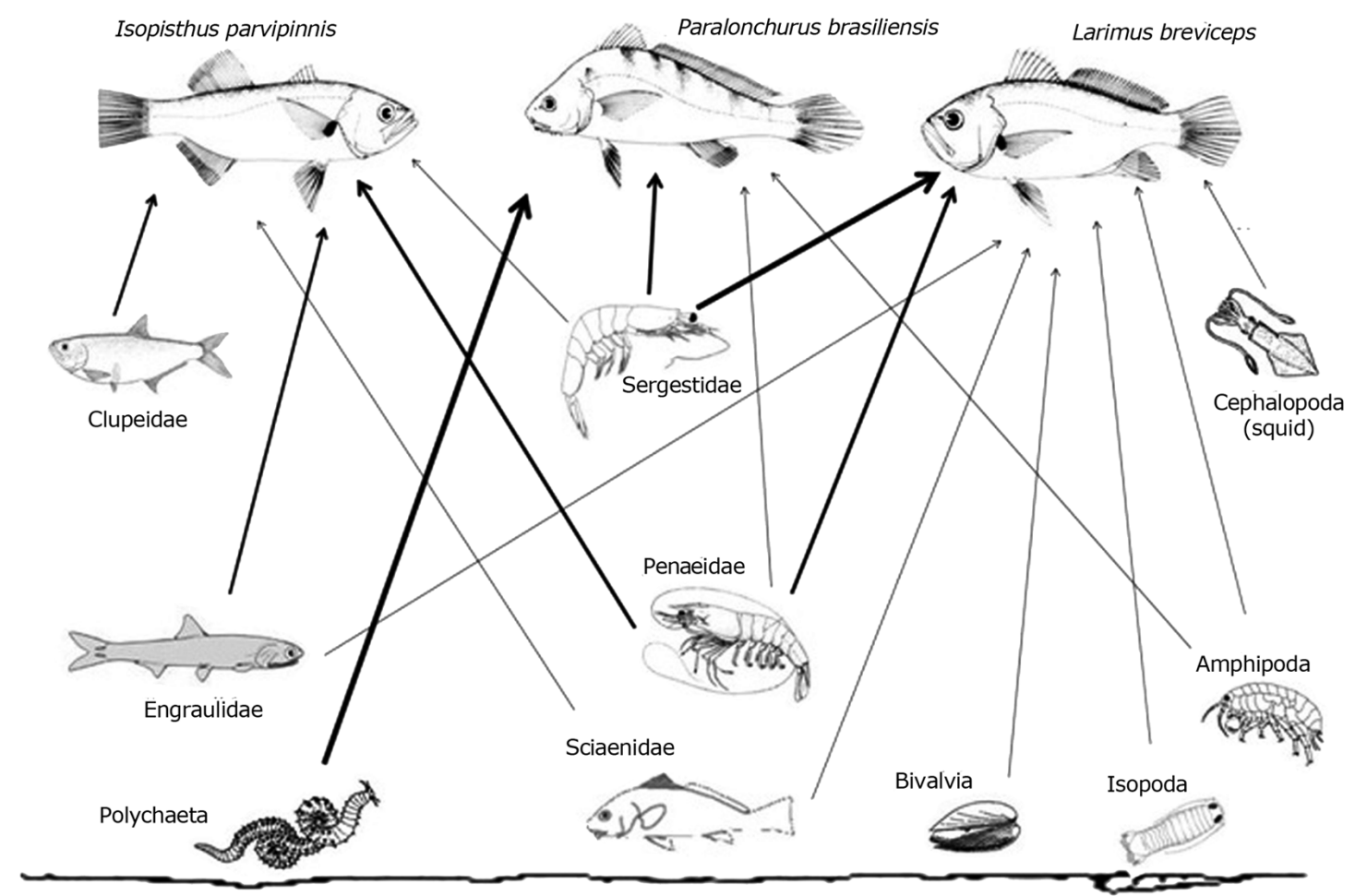

Figure 4. Trophic interactions among the three most abundant sciaenids in the ResexCor based on frequency of occurrence (\%F0) of food items found in the stomach content. The width of the arrows is proportional to the FO of each item in the diet of each species as defined / Interacciones tróficas entre las tres especies abundantes de Sciaenidae en la ResexCor basado en la frecuencia de ocurrencia (\%FO) de ítems encontrados en el contenido estomacal. La largura de las setas es proporcional a FO de cada ítem en la dieta de cada especie como definido 
Very high indexes of overlap were observed only in the winter between $P$. brasiliensis and L. breviceps $\left(\mathrm{CH}_{\mathrm{jk}}=0.95\right)$ and between $P$. brasiliensis and I. parvipinnis $\left(\mathrm{CH}_{\mathrm{jk}}=0.83\right)$, due to the high abundance of Dendrobranchiata shrimps in the diet of the three species (Tables 1 and 4).

On the other hand, L. breviceps and I. parvipinnis showed diet overlap higher than $80 \%$ in all seasons, except in summer $\left(\mathrm{CH}_{\mathrm{jk}}=0.56\right)$. During this season, the IAi for Dendrobranchiata shrimps was about twice as higher as for L. breviceps. However, besides the abundance of Dendrobranchiata in both diets, Sergestidae was more important to L. breviceps mainly in the fall (26.2\%), while Penaeidae showed higher IA in the diet of I. parvipinnis.

For the 3 species of Sciaenidae, the trophic relations studied in the ResexCor seem to indicate low food overlap between $P$. brasiliensis and each of the other 2 species (except during winter), and high diet overlap between $L$. breviceps and $I$. parvipinnis. This is represented in Figure 4 where the thickness of the arrow is proportional to the frequency of occurrence $(\% \mathrm{FO})$.

\section{Discussion}

Morphological characteristics such as mouth orientation, shape, and size are related to the feeding habit of a species, and indicate how fishes locate and feed on its prey (Zavala-Camin 1996, Karpouzi \& Stergiou 2003). In general, the overall mouth shape is similar among fish species but its detailed structure presents a wide variation from one group to another, allowing some species to feed upon a large variety of resources. However, the nature of the ingested food does not depend only on the morphological characteristics of the mouth, but also on the composition and availability of the resources in the environment (Berg 1979, Gerking 1994).

According to the Optimal Foraging Theory, species are capable of taking advantage of the abundance of a certain resource. Thus, the most abundant resource will usually be the most consumed by individuals (Gerking 1994, Hughes 1997). This might occur due to the absence, low abundance, or difficulty to capture the food of preference, leading the species to exploit other resources available in higher abundance than preferred prey. This is called trophic adaptability, which is responsible for changes in food habits in response to daily or seasonal variation in food availability (Gerking 1994, Lowe-McConnell 1999).

The importance of polychaetes in the diet of $P$. brasiliensis in the ResexCor was similar to that observed off southern Paraná, with FO exceeding 40\% (Robert et al. 2007) and around $69 \%$ in the coast of the State of São Paulo (Jucá-Chagas
1997, Soares \& Vazzoler 2001). However, these authors did not observe the same importance that shrimps had in our study area. The importance of polychaetes in the diet of sciaenids was also reported by Bertrán et al. (2013) for Micropogonias furnieri in Chile. Additionally, Robert et al. (2007) and Soares \& Vazzoler (2001) observed the presence of fishes in the diet of $P$. brasiliensis, a food category of minor importance for this species in the ResexCor $(0.8 \%)$.

The consumption of pelagic shrimps (Sergestidae) by $P$. brasiliensis in the study area was unexpected due to the mouth orientation of this species and its common benthivorous feeding habits. Gerking (1994) considers that, although the trophic adaptability is limited by mouth morphology, feeding behavior, and digestion capacity, it is not possible to predict the responses of consumers due to changes in the abundance of their prey. In this study, no information on the abundance of the prey was obtained and the limited sampling period did not allow for the assessment of possible changes in diet composition associated with a decrease in the abundance of preferred prey. Moreover, benthivorous predators have more diverse feeding habits than any other group. Even fishes that have extreme morphological specializations in their digestive tract will be able to use a variety of food categories according to their availability in the habitat at certain periods (Lowe-McConnell 1999). Therefore, by taking advantage of a food source that is not common in its diet, $P$. brasiliensis may be considered as an opportunistic species, able to catch and eat other less preferred prey whenever its preferred prey is overexploited or in low abundance (Gerking 1994). Thus, these possible supply fluctuations, in addition to the limited opening of its mouth proportional to the size of the ingested Sergestidae, may have contributed to the observed change in the diet of P. brasiliensis.

According to Zavala-Camin (1996), the consumption of solid food is usually a cyclic activity comprising ingestion, digestion, and rest. The latter corresponds to a period when the stomach remains empty. Although Soares \& Vazzoler (2001) have not found strong evidence of a daily feeding pattern for $P$. brasiliensis, they observed a larger consumption of food items in the afternoon. A similar pattern was observed by these authors for $L$. breviceps, whose major consumption was registered at dusk and at night, and for I. parvipinnis, which fed mainly in the afternoon, with some feeding activity at night. In this study, samples were collected only in the morning, leading to the capture of individuals with prey in advanced digestion stages. Therefore, the time of the capture is a factor that may cause quantitative changes in diet, in addition to factors such as the digestibility of the item. This might contribute to an overestimate of how many items were actually ingested, as carapace and pereiopods of crustaceans can stay longer in the stomach than 
polychaetes, which have soft and easily digestible body (Fonteles-Filho 2011).

According to Lowe-McConnell (1999), L. breviceps preys upon pelagic shrimps (Sergestidae), a feeding habit facilitated by their oblique, tilted up mouth. Studying the morphological aspects related to feeding, such as mouth orientation and shape and the arrangement of teeth, Jucá-Chagas (1997) found that shrimps and fishes are the most consumed category by various sciaenids off the state of São Paulo. Similarly to the results found in the ResexCor, Sergestidae shrimps were the most important food category in the diet of L. breviceps and I. parvipinnis. Dendrobranchiata and fishes were also the most important food items in the diet of I. parvipinnis off Ilhéus, in the state of Bahia (Romero et al. 2008). For L. breviceps, as for the other studied species, the mouth orientation was in accordance with the position occupied by its prey types available in the environment. When open, the mouth orientation of L. breviceps and $I$. parvipinnis is terminal (Fig. 2), a position adequate to capture pelagic items. On the other hand, the mouth of $P$. brasiliensis is sub-terminal (Fig. 2), properly fitted for catching benthic organisms such as polychaetes.

Analyzing the diet of juveniles of $L$. breviceps in Itaparica Island (Bahia), Moraes et al. (2004) observed Dendrobranchiata as one of the most frequent food categories, especially in summer. These results are similar to those found in the ResexCor, where this category was more frequent in spring and summer. In the study area, Cephalopoda, Isopoda, Bivalvia, and Amphipoda were considered occasional food resources, according to the definitions given by Fonteles-Filho (2011). The same result was found off the State of São Paulo and in Itaparica, in the state of Bahia (Jucá-Chagas 1997, Moraes et al. 2004).

Cannibalism in the diet of L. breviceps in the ResexCor was registered. Fishes were identified only to the family level due to the high degree of digestion of the food items. However, the oblique mouth and other morphological characteristics of these items are typical of L. breviceps, which indicates the presence of co-specific individuals in the stomach contents in the study area. Cannibalism was also reported in the diet of L. breviceps (Moraes et al. 2001, 2004) and Macrodon ancylodon (Figueiredo et al. 2014). According to Smith \& Reay (1991), cannibalism may be considered as a type of predation with potential to regulate population density, being especially observed in piscivorous species or those exhibiting high levels of parental care. Smith \& Reay (1991) list 35 families of marine and freshwater fishes in which cannibalism was recorded; however, Sciaenidae was not cited.
The ingestion of shrimps and fishes was observed in all 3 sciaenids analyzed here. However, minor differences in the diet should allow for more efficient exploitation of food resources, benefitting several species (Gerking 1994, Lowe-McConnell 1999). Some differentiation was observed for $L$. breviceps due to its higher efficiency to capture Sergestidae, which allows for higher consumption of this group in relation to other groups. $L$. breviceps is one of the sciaenids with the highest values of mouth height and width (Jucá-Chagas 1997), allowing it to capture a high number of Sergestidae during the feeding activity.

The species' niche breadth measures its level of specialization related to the use of local resources (Colwell \& Futuyma 1971). Specialist species feed upon one or two food sources and will have a lower value of niche breadth than generalist species, which feed on many food categories (Colwell \& Futuyma 1971, Gerking 1994). The high importance of shrimps and fishes in the diet of the three species analyzed in the ResexCor indicates that they exploit essentially the same resources, with a minor degree of differentiation, even though there is evident difference in the orientation of their mouth, accepting the initial hypothesis of low diet overlap. This could be related to the high local abundance of Dendrobranchiata shrimps in the study area. Muto et al. (2014) also categorized these 3 species in different trophic groups due to differences in the main ingested prey. However, more studies will be necessary on the diet of these species, with a more detailed taxonomic analysis of the food items (not possible here due to the high degree of digestion of stomach contents) and a more representative sampling scheme to further explore how food sharing takes place among these three locally abundant sciaenids.

\section{ACKNOWLEDGMENTS}

The authors would like to thank the Coordenação de Aperfeiçoamento de Pessoal de Nível Superior (CAPES) for the scholarship for the first author; Fundação de Amparo à Pesquisa do Estado da Bahia (FAPESB) for financing the project; MSc. Bruna Tanure and fisher Ita for helping during the sampling process; Dr. Alexandre Almeida for identifying the shrimps; Dr. Erminda C. G. Couto and Dr. Fernanda J. Guimarães for the invitation to participate in the ResexCor Project; and M. J. Malon for revising a first version of this manuscript.

\section{LITERATURE CITED}

Alverson DL, MH Freeberg, SA Murawski \& J Pope. 1994. Estimates of fisheries bycatch and discards. Chapter 1. In: A global assessment of fisheries bycatch and discards. FAO Fisheries Technical Paper 339: 1-233. <http:// www.fao.org/docrep/003/t4890e/t4890e00.htm> 
Bail GC \& JO Branco. 2003. Ocorrência, abundância e diversidade da ictiofauna na pesca do camarão sete-barbas, na região de Penha, SC. Notas Técnicas Facimar 7: 73-82.

Begon M, M Mortimer \& DJ Thompson. 1996. Population ecology: a unified study of animal and plants, $245 \mathrm{pp}$. Blackwell Science, Oxford.

Berg J. 1979. Discussion of methods of investigating the food of fishes, with reference to a preliminary study of the prey of Gobiusculus avescens (Gobiidae). Marine Biology 50(3): 263-273. <DOI: 10.1007/BF00394208>

Bertrán C, C Jiménez, P Fierro, F Peña-Cortés, J Tapia, E Hauenstein \& L Vargas-Chacoff. 2013. Feeding of Micropogonias furnieri (Osteichthyes: Sciaenidae) in Budi coastal lagoon, southern Chile. Revista de Biología Marina y Oceanografía 48(1): 193-197. <DOI: 10.4067/S071819572013000100017>

Bessa E, FB Santos, M Pomboa, M Denadaia, M Fonseca \& A Turra. 2014. Population ecology, life history and diet of the shorthead drum Larimus breviceps in a tropical bight in southeastern Brazil. Journal of the Marine Biological Association of the United Kingdom 94(3): 615-622. <DOI:10.1017/S0025315413001690〉.

Colwell RK \& DJ Futuyma. 1971. On the measurement of niche breadth and overlap. Ecology 52(4): 567-576. <doi: 10.2307/1934144>

Deus CP \& M Petrere-Júnior. 2003. Seasonal diet shifts of seven fish species in an Atlantic Rainforest Stream in southeastern Brazil. Brazilian Journal of Biology 63(4): 579588. <doi: 10.1590/S1519-69842003000400005>

Figueiredo MB, RNF Carvalho-Neta, JLS Nunes \& ZS Almeida. 2014. Feeding habits of Macrodon ancylodon (Actinopterygii, Sciaenidae, northeast Brazil). Revista de Biología Marina y Oceanografia 49(3): 559-566.

Fonteles-Filho AA. 2001. Oceanografia, biologia e dinâmica populacional de recursos pesqueiros, 460 pp. Expressão Gráfica e Editora, Fortaleza.

Freire KMF, V Christensen \& D Pauly. 2008. Description of the East Brazil Large Marine Ecosystem using a trophic model. Scientia Marina 72(3): 477-491.

Froese R \& D Pauly. 2016. FishBase. <www.fishbase.org>

Fugi R, AA Agostinho \& NS Hahn. 2001. Trophic morphology of five benthic-feeding fish species of a tropical foodplain. Brazilian Journal of Biology 61(1): 27-33.

Gerking SD. 1994. Feeding ecology of fish, 416 pp. Academic Press, San Diego.

Hughes RN. 1997. Diet selection. In: Godin J (ed). Behavioural ecology of teleost fishes, pp. 134-162. Oxford University Press, Oxford.

Hyslop EJ. 1980. Stomach contents analysis: a review of methods and their applications. Journal of Fish Biology 17(4): 411-429. <doi: 10.1111/j.1095-8649.1980.tb02775.x>
Jucá-Chagas R. 1997. Morfologia funcional relacionada à alimentação em Sciaenidae do litoral do Estado de São Paulo. PhD Thesis, Universidade Estadual Paulista, Rio Claro, 154 pp.

Karpouzi VS \& KI Stergiou. 2003. The relationships between mouth size and shape and body length for 18 species of marine fishes and their trophic implications. Journal of Fish Biology 62(6): 1353-1365. <doi: 10.1046/j.1095-8649.2003.00118.x>

Kawakami E \& G Vazzoler. 1980. Método gráfico e estimativa de índice alimentar aplicado no estudo de alimentação de peixes. Boletim do Instituto Oceanográfico 29: 205-207.

Krebs CJ. 1989. Ecological methodology, 654 pp. Harper \& Row Publishers, New York.

López-Peralta RH \& CAT Arcila. 2002. Diet composition of fish species from the southern continental shelf of Colombia. Naga, WorldFish Center Quarterly 25(3\&4): 23-29.

Lowe-McConnell RH. 1999. Estudos ecológicos de comunidades de peixes tropicais, 373 pp. EDUSP, São Paulo.

Menezes NA \& JL Figueiredo. 1980. Manual de peixes marinhos do sudeste do Brasil. IV. Teleostei 3: 1- 96. Museu de Zoologia da Universidade de São Paulo, São Paulo.

Meyer M \& MJ Smaller. 1991. Predation patterns of demersal teleosts from the Cape South and west coasts of South Africa. 1. Pelagic predators. South African Journal of Marine Science 10(1): 173-191.

Moraes LE, JTO Silva \& PRD Lopes. 2001. Canibalismo em Larimus breviceps (Cuvier, 1830) (Actinopterygii: Sciaenidae) na Praia de Ponta da Ilha (Ilha de Itaparica), Bahia. Multitemas 22: 63-68.

Moraes LE, PRD Lopes \& JT Oliveira-Silva. 2004. Alimentação de juvenis de Larimus breviceps (Curvier, 1830) (Pisces: Actinopterygii: Sciaenidae) na praia de Ponta da Ilha (Ilha de Itaparica, Bahia). Revista de Ciências Exatas e Naturais 6(2): 245-256.

Muto EY. 1989. Alimentação de Isopisthus parvipinnis (Teleostei: Sciaenidae) na Baía de Santos, São Paulo. Boletim do Instituto Oceanográfico 37(2): 95-105.

Muto EY, LSH Soares \& R Goitein. 2001. Food resource utilization of the skates Rioraja agassizii (Muller and Henle, 1984) and Psammobatis extenta (Garman, 1913) on the continental shelf off Ubatuba, south-eastern Brazil. Revista Brasileira de Biologia 61(2): 217-238.

Muto EY, TN Corbisier, LI Coelho, LPLArantes, A Chalom \& LSH Soares. 2014. Trophic groups of demersal fish of Santos Bay and adjacent continental shelf, São Paulo state, Brazil: temporal and spatial comparisons. Brazilian Journal of Oceanography 62(2): 89-102. <DOI: http://dx.doi.org/ 10.1590/S1679-87592014045906202>

Robert MC, MAM Souza \& PTC Chaves. 2007. Biologia de Paralonchurus brasiliensis (Steindachner) (Teleostei, Sciaenidae) no litoral sul do estado do Paraná, Brasil. Revista Brasileira de Zoologia 24(1): 191-198. 
Rocha GRA, CLDB Rossi-Wongtschowski, AMS PiresVanin \& LSH Soares. 2007. Trophic models of São Sebastião Channel and continental shelf systems, SE Brazil. Pan-American Journal of Aquatic Sciences 2(2): 149-162.

Romero RM, LE Moraes, MN Santos, M Cetra \& GRA Rocha. 2008. Biology of Isopisthus parvipinnis: an abundant sciaenid species captured bycatch during sea-bob shrimp fishery in Brazil. Neotropical Ichthyology 6(1): 6774. <DOI: $10.1590 / \mathrm{S} 1679-62252008000100008>$

Ross ST. 1986. Resource partitioning in fish assemblages: a review of field studies. Copeia 2: 352-388.

Ruppert EE \& RD Barnes. 1996. Zoologia dos invertebrados, 1029 pp. Editora Roca, São Paulo.

Smith C \& P Reay. 1991. Cannibalism in teleost fishes. Reviews in Fish Biology and Fisheries 1(1): 41-64. <doi: 10.1007/BF00042661>
Soares LSH. 1989. Alimentação de Isopisthus parvipinnis (Teleostei: Sciaenidae) na Baía de Santos, São Paulo. Boletim do Instituto Oceanográfico 37(2): 95-105.

Soares LSH \& AEAM Vazzoler. 2001. Diel changes in food and feeding activity of sciaenid fishes from the southwestern Atlantic, Brazil. Revista Brasileira de Biologia 61(2): 197216.

Vazzoler AEAM. 1996. Biologia da reprodução de peixes teleósteos: teoria e prática, 169 pp. EDUEM, Maringá.

Zavala-Camin LA. 1996. Introdução aos estudos sobre alimentação natural em peixes, 129 pp. EDUEM, Maringá.

Received 22 July 2015 and accepted 10 June 2016

Associate Editor: Patricio Ojeda R. 